\title{
THE IMPACT OF THE GROWTH AND PRODUCTIVITY OF INHIBITION OF ONION SEEDS BY VARIOUS VEGETABLE PARTS
}

\author{
Mirzaosimjon Mirzasoyipovich Mirzasoliev \\ Independent Researcher, Vegetable, Melon and Potato Growing Department, Tashkent State Agrarian University, Tashkent, \\ Uzbekistan \\ Shukhrat Ismatovich Asatov \\ Professor of Vegetable, Melon and Potato Growing Department, Doctor of Agricultural Sciences, \\ Tashkent State Agrarian University, Tashkent, Uzbekistan
}

DOI: https://doi.org/10.36713/epra3757

\begin{abstract}
The article provides information on the importance of onion and the volume of its production in the leading countries of the world. It also describes the timing of cultivation in dry hot climates of the Republic, how one-third of its leaves and roots are affected by its viability, duration, growth and development stages, productivity and yield quality. At the same time there is a scientific basis for reducing the number of crop failures and increasing the yield by $4.2 \mathrm{t} / \mathrm{ha}$.

KEYWORDS: Onions, varieties, seeds, plants, seedlings, planting scheme, harvesting, breeding.
\end{abstract}

\section{INTRODUCTION}

Onions have been planted on 4,444 million hectares worldwide, of which 85,795 million tons are grown, with an average yield of $19.31 \mathrm{t} / \mathrm{ha}$. China (22,345 million tons), India (19,299 million tons), the USA (3,159 million tons) and Iran (2,382 million tons) are the leaders in the production of onion [5]. At the same time, onions are one of the major crops in the European vegetable sector.

Onion seed is of great importance as a food and medicinal plant.

Onions in Uzbekistan, onions are grown in three terms (early spring, August and 90). For this reason, onions are second in the list of major vegetables in terms of area and high yield.

Not only the local population is provided with the onion crop, but some of its crop is exported to neighboring countries. This is due to the fact that Central Asia has a favorable climate for growing onions that are complete in one year. There are 50-60 days sowing of onions in regions where effective temperatures are not sufficient for the growth and development of the onion [1].

At the same time, the sources also indicate that cutting the leaves and roots of onions before planting can contribute to their growth and development $[3,4,6$, 7].

In our conditions, one of the reserves of increasing the onion yield, as a second crop of saplings, is the cultivation of seeds of cabbage, potatoes, cucumbers and other crops, which is one of the topical issues of vegetable production.

The technology of growing onions as a secondary crop and sowing the leaves and roots by one-third has not been studied in our country.

To investigate this issue, a study was undertaken to study the impact of 45-50-day onion sowing on the growth, development and productivity of the root and leaf trunks.

Onions were planted in the second decade of March in a $4 \times 1 \mathrm{~cm}$ scheme with a $45-50$-day planting in the usual manner near the test site $-5 \mathrm{~m}^{2}$.

\section{MATERIALS AND METHODS}

Field experiments were conducted in 2016-2018 on the experimental ground of SUE "Innovation and Consulting Markets in Agriculture" of the Tashkent DAU, located in the Tashkent region of the Republic of Uzbekistan [2]. The experiment was carried out on the Istiqbol variety of onions, which was planted in $3-\mathrm{m}$ long furrows in a $3 \times 3-\mathrm{cm}$ scheme in a $7.5 \mathrm{~cm}$ scheme with 571,400 seedlings per hectare. The surface of the site with vegetation counting at each repeat is $2.1 \mathrm{~m}^{2}$. Each ribbon was planted 40 seedlings per tape, since the 
ribbon consisted of three tapes, the number of seedlings per duplication was 120 .

\section{RESULTS AND DISCUSSION}

Phenological, biometric and other observations made at the experimental site revealed the following.

The growth and development of onion seedlings planted in the second decade of June differed in terms of experience variants. That is, on June 12, the seedlings planted an average of $3.6 \ldots 3.8$ leaves, yielding the fifth and sixth leaves in 14 to 18 days of sowing.

It should be noted that at the stage of yellowing leaves, the number of leaves of each bush is 1.8 , and 2.7 $\mathrm{cm}$ higher than the number of leaves.
Sowing leaves and roots also affected the onset of onion formation. The onion pruning of leaves and stem leaves was observed 26 days after sowing and 58 days after leaves. In germination variants, these stages occur after 33 and 68 days, in saplings 28 and 61 days, and in saplings 33 and 70 days, respectively.

This means that the sowing of onions by a certain part of the upper and the underground vegetative parts has a significant impact on the development stages.

The sowing of the seedlings above and below the soil has also affected their survival (Table 1).

Table 1 Effect of error on sowing of onions by different vegetative parts on repeated crop (average for 2016-2018)

\begin{tabular}{|c|c|c|c|c|c|c|}
\hline & \multicolumn{4}{|c|}{ Error rate,\% } & \multicolumn{2}{c|}{ Total } \\
\cline { 2 - 6 } $\begin{array}{c}\text { Experience } \\
\text { options }\end{array}$ & $\begin{array}{c}\mathbf{1 0} \text { days } \\
\text { after } \\
\text { planting }\end{array}$ & $\begin{array}{c}\mathbf{2 0} \\
\text { days } \\
\text { later }\end{array}$ & $\begin{array}{c}\text { When the } \\
\text { leaves turn } \\
\text { yellow }\end{array}$ & Total & $\begin{array}{c}\text { Number of } \\
\text { perennial } \\
\text { shoots, thous } \\
\text { spit/ha }\end{array}$ & $\begin{array}{c}\text { Actual } \\
\text { number of } \\
\text { plants per } \\
\text { hectare, thous } \\
\text { spit/ha }\end{array}$ \\
\hline $\begin{array}{c}\text { The leaves and roots were } \\
\text { sown without breaking }\end{array}$ & 11,3 & 3,1 & 1,0 & 15,4 & 87995 & 483400 \\
\hline Part of the root is sown & 15,1 & 5,2 & 1,6 & 21,9 & 119420 & 451990 \\
\hline Part of the leaf was sown & 9,0 & 1,2 & 0,8 & 11,0 & 62830 & 508570 \\
\hline $\begin{array}{c}\text { The leaves and roots are } \\
\text { sown }\end{array}$ & 9,8 & 2,9 & 1,0 & 13,7 & 78260 & 493140 \\
\hline
\end{tabular}

Observations (Table 1) show that, within 10 days after planting the first variant germination, the error rate was $11.3 \%$, after 20 days - $3.1 \%$, and the leaves yellowish $-1.0 \%$, with a total error rate of $15,4 \%$.

It is found that the total error rate of the root-cut variants is $-21.9 \%$, or $35.7 \%$ higher than the error of the first variant.

The error of the third and fourth versions of the experiment was $11.0 ; 13.7 \%$ or $4.4 \%$ and $1.7 \%$ decrease respectively. The second option is that the germination is viable - the error rate is $6.5 \%$ higher than the first option, and, in our opinion, the root system is not able to provide the leaves with water and nutrients. Only a small percentage $(11.0 \%)$ of the planted leaves can easily grow roots and provide enough nutrients to the surface. The fourth variation of leaf and root crop was $13.7 \%$, which was $1.7 \%$ less than all sown, due to the correlation between the ground and the top of the seedlings. It is important to note that only partial cuttings can cause a dramatic increase in the error rate $(21.9 \%)$.

The number of errors per hectare of actual plants per hectare was 119,420 , from the 62830 plants, regardless of whether the error rate was more or less the effect of the technology learned in the experiment. This, in turn, affected the crop yield per hectare.

The amount and quality of harvest per unit area and hectare depends on the number of seedlings per field (Table 2).

Observations (Table 2) show that the onion germination, or sowing leaves and roots, has a significant effect on yield and quality.

The first variant of the experiment yields an average of 34.6 tons per hectare, and plants of the second, third and fourth versions, respectively: 30.4; 38.7 and $31.7 \mathrm{t}$. formed from. Commodity products in the total yield are varied by $32.7 ; 28.9 ; 37.2$ and $29.7 \mathrm{t}$. range. The average weight of turbopers is $91.0 \ldots 111.5$ g.

It was found that there is a significant difference in the amount of mature and immature bulbs in the commodity crop produced by the technology used.

In the first variant of the experiment, 92.5\% (30.2 $\mathrm{t}$ / ha) of the complete bulbs and the incomplete $2.0 \%$ (2.5 t / ha), the average weight of onions was $111.5 \mathrm{~g}$. was formed. 
Table 2 Impact of sowing various vegetative parts of onion seedlings on crop yield and product
quality (Average for 2016-2018)

\begin{tabular}{|c|c|c|c|c|c|c|c|c|c|c|c|}
\hline \multirow[b]{3}{*}{$\begin{array}{l}\text { Experience } \\
\text { options }\end{array}$} & \multirow[b]{3}{*}{ 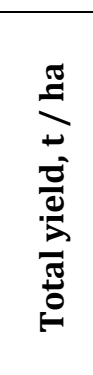 } & \multirow{2}{*}{\multicolumn{3}{|c|}{$\begin{array}{l}\text { From this, a } \\
\text { commodity crop }\end{array}$}} & \multicolumn{6}{|c|}{ The composition of cabbage } & \multirow{3}{*}{ 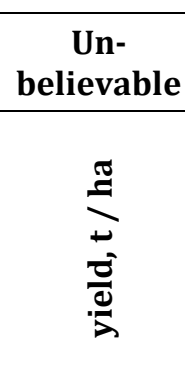 } \\
\hline & & & & & \multicolumn{3}{|c|}{ complete } & \multicolumn{3}{|c|}{ incomplete } & \\
\hline & & 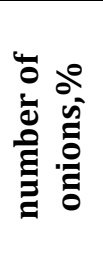 & $\begin{array}{l}\frac{\pi}{3} \\
\frac{\pi}{2} \\
\frac{0}{2}\end{array}$ & 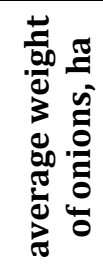 & 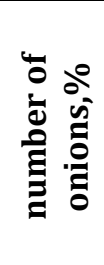 & $\begin{array}{l}\frac{\pi}{3} \\
\pm \\
\frac{0}{0} \\
\frac{0}{2}\end{array}$ & 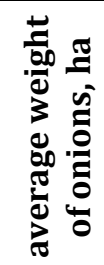 & 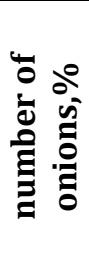 & 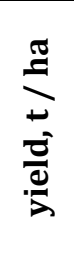 & 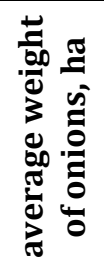 & \\
\hline $\begin{array}{l}\text { Leaves and roots } \\
\text { are sown without } \\
\text { interruption }\end{array}$ & 34,6 & 94,5 & 32,7 & 111,5 & 92,5 & 30,2 & 118,2 & 2,0 & 2,5 & 104,8 & 1,9 \\
\hline $\begin{array}{l}\text { Sowing the root } \\
\text { part by cutting }\end{array}$ & 30,4 & 95,1 & 28,9 & 95,7 & 89,3 & 25,8 & 104,9 & 5,8 & 3,1 & 86,5 & 1,5 \\
\hline Sow leaf partition & 38,7 & 93,5 & 37,2 & 91,0 & 92,1 & 34,3 & 110,1 & 1,4 & 2,9 & 72,0 & 1,0 \\
\hline $\begin{array}{l}\text { Sowing the root } \\
\text { and leaf partially }\end{array}$ & 31,7 & 93,7 & 29,7 & 101,3 & 90,1 & 26,8 & 116,1 & 3,6 & 2,9 & 86,5 & 2,0 \\
\hline
\end{tabular}

$95.1 \%$ of the crop yielded by saplings, and onions, did not exceed $95.7 \mathrm{~g}$. The full yield of this variant is 25.8 t. (89.3\%), incomplete $-3.1 \mathrm{t}(5.8 \%)$. Among the methods studied, the variants planted with leaves yield the highest yield (37.2 t) per hectare and the average weight of onions is $91.0 \mathrm{~g}$. was formed. The fourth variant of the tested technology is 29.7 tons per hectare. The bulbous onions did not exceed $101.3 \mathrm{~g}$ on average.

The third experiment yields germination more common (38.7 t/ha) and more commercially viable

\section{CONCLUSION}

Sowing onions by $45-50$ days sapling reduced the error rate for planting whole saplings by $4.4 \%$.

Sowing the sapling part of the plant resulted in an increase in the error rate per hectare $(21.9 \%)$.

Sowing the leaves of the sprig provides additional commercial yield of $4.2 \mathrm{t} /$ ha per hectare compared to the first variant plants.

Reproduction of 45-50-day onion seedlings will double the productivity of irrigated land.

\section{REFERENCES}

1. Alekseyeva M.V. (1982). Repchatiy luk [Onions]. Moscow: Rosselkhozizdat, 112 p. (in Russian)

2. Dospekhov B.A. (1985). Metodika polevogo opyta [Methods on field experiments]. Moscow: Agropromizdat, 351 p. (in Russian)

3. Kazakova A.A. (1970). Luk [Onion]. Leningrad: Kolos, 360 p. (in Russian)

4. Kazakova A.A., Komarova R.A. (1973). Ranniy ovoshi $v$ otkrytom grunte [Early vegetables in the open ground], Leningrad: Kolos, 56 p. (in Russian)

5. Mamedov M.M. (2015). Proizvodstvo osnovnykh ovoshchnykh kul'tur: tendensiya razvitiya za 1993-2013 gody po dannym FAO [Production of main vegetable crops: development trend for 1993-2013 according to the FAOJ. Ovoshch Rossii, 2 (27): 3-9. (in Russian)

6. Mukhin V.D. (2000). Priusadebnoe khozyaystvo. Ovoshchevodstvo [Homestead farming. Vegetable yields $(37.2 \mathrm{t} / \mathrm{ha})$, in our opinion, due to better leaf root development and better water and nutrients. This is due to the drastic reduction of the error rate and sufficient bulk (85.3 g) of bulbous bulbs.

This means that in the cultivation of onion as a second crop of Istiqbol varieties, it will be a promising method for sowing the seeds of germination in the second half of June and freeing them from the vegetables in the second half of June.

growing]. Moscow: Lik-Press, Eksmo-Press, 368 p. (in Russian)

7. Putyrsky I.N., Prokhorov V., Rodionov P. (2000). Luk $i$ chesnok [Onion and garlic]. Knijny dom: Makhaon, 96 p. (in Russian)

| Volume: 4 | Issue: 11 | November| 2019 Journal DOI: https://doi.org/10.36713/epra2016 |www.eprajournals.com |58 | 